\title{
The Arab City - Reality, Fiction, and Affect on Culture and Civilization
}

\author{
Mamadou Salif Diallo ${ }^{1} \&$ Abdullah H. Alfauzan ${ }^{1}$ \\ ${ }^{1}$ College of Arabic \& Social Studies, Qassim University, Buraydah, Saudi Arabia \\ Correspondence: Abdullah H. Alfauzan, College of Arabic \& Social Studies, Qassim University, Buraydah, Saudi \\ Arabia PO Box 12308, ZIP51473. Tel: 96-61-6380-0050 Ext 1859. E-mail: aaf741@gmail.com \& \\ amsakhou@yahoo.com
}

Received: February 15, 2017

Accepted: March 2, 2017 Online Published: June 23, 2017

doi:10.5539/ass.v13n7p16

URL: https://doi.org/10.5539/ass.v13n7p16

\begin{abstract}
The increasing urbanization of the Arab world, especially the emergence of huge and ultra-modern cities such as Riyadh, Dubai, and Doha in the Arab Gulf, has renewed discussions and even debates on the nature of the Arabian civilization. Some people maintain that urban places such as the above-mentioned are only copies of Western cities within Arabia, and that there is no such thing as an Arab city, socioculturally speaking. This debate has also taken place informally in the office of the English Department at Qassim University, in a spare time that a number of faculty and staff (including the authors of this article) happened to have. We decided to take it further and look into the question more deeply. Therefore, we covered some relevant literature, including Islam's important perspective on the issue. We eventually came up with the conclusion that the Arab city does exist and has existed long before the Industrial Revolution. Accounts of real and fictional cities in the Arab world, predating the industrial era, prove the validity of this assertion. Without advocating seclusion or withdrawal into themselves, we think that Arabs should stop thinking they owe the concepts of city, urbanization and therefore civilization to the West. There is certainly a lot that can be learned from each other on both sides, but importing everything wholesale from the West can only result in increasing social problems.
\end{abstract}

Keywords: Perception of Arab city, industrial revolution, urbanization, western city

\section{Introduction}

What are perceptions of the city in the Arab world? Are they real or fictional? Is there any such thing as the Arab city, or can cities only be defined with regard to the precedence of the Industrial Revolution? How does the would-be Arab city compare with other cities, in particular European and North American cities? These are broad questions discussed in the article in light of pertaining readings done on the theme.

We decided that it would not be instructive to conduct interviews as average individuals may not know what constitutes a city; they may lack awareness of historical, cultural, sociological, elements that make cities. Moreover, for ordinary people who have some understanding of these concepts, it would be difficult to express the distinctive features of diverse urban civilizations. However, we thought distributing a questionnaire could help as this would give people more time to think over and prepare their answers. Therefore, we based our paper on the answers to our questionnaire, literature we reviewed and our understanding of its contents. The researchers also aim at finding answers to the following questions so as to establish perceptions of the Arab city, compare it with other cities and most importantly suggest the possibilities of a fruitful dialog between both concepts:

1. What are the perceptions of the city in the Arab world?

2. Is there any such thing as the Arab city?

3. Can cities only be defined in relation to the Industrial Revolution?

4. How does the would-be Arab city compare with other cities, in particular European or North American cities?

5. What are the affects of the Arab city on culture and civilization?

\subsection{Significance of the Study}

With the boiling situation prevailing in many countries across the Arab world, a number of questions need asking, including why the chaos and how it can be resolved. The profound disorder if not disintegration of some Arab 
countries may be due to the setting up of western ways of living in societies the most different. These ways may include the imposition of western-type urbanization upon not always accepting populations.

"The sudden introduction of foreign concepts and practices has disrupted society, and interaction between Arabs and Westerners has resulted in conflicts in some cases. It has also led to a division within society between those who feel that change is necessary for progress and those who feel that change is an assault of Western morals and values on their societies. (G-Mrabet, 2012)"

The overlapping of these sometimes antagonistic realities without preparation may be one recipe for the inedible situation the world is served. Understanding the cocktail fueling this infernal machine with its burning nuts and bolts can be a step in mitigating its destructive work. This is why we decided to take part in the discussion.

\subsection{Literature Review}

For many writers, whether there is such a thing as the Arab city is a non-issue. They take a step ahead and discuss its characteristics rather. In the abstract to his Introduction to the Islamic City (2002), Saoud states:

"Islam made particular emphasis on the form and design of the city enabling it a greater functionality and responsiveness to meet the socio-economic and cultural needs of the community."

This article analyzes the spatial and functional arrangements of the Muslim city and assesses their socio-cultural meanings. The author asserts that since its advent, Islam has had a great impact on urbanization by developing cities to help spread the Faith and organize their dwellers' social life. Thereafter, cities became indispensable for citizens to perpetuate their new-found stable, peaceful, secure, and prosperous living conditions; and for rulers to fortify and preserve their power. Eventually, colonial powers from Europe conquered and took over the control of Muslim cities, initiating the alteration of both their morphology and their structural coherence and cohesion.

The disfiguration of the Arab city may pose a problem; however, seclusion and closure are not likely solutions to resolve it. From Abdelmeguid's (2014) perspective, it is the very exclusion of others that is causing the problems faced. He imagines older Alexandria that never ceased to be Arab in spite of the religious, ethnic, and cultural mix that characterized the place. Freedom, he contends, should not necessarily be incompatible with Arabism. In the past, Alexandria had been Arab, international, and free. In other words, it was a free Arab city, not exclusive of other faiths, cultures, and other differences. Now, Abdelmeguid argues, it has lost not only its global stature, but also its Egyptian spirit.

The negative transformation of Alexandria would be representative of the downfall of the Arab city hence civilization - with entailments such as the Arab Spring - and characterized by its cosmopolite nature. For Abdelmeguid, religion should not be the only one criterion to define a city. Apparently, when the city's identity is lost, the city loses, and when the city loses, culture and civilization do; with them, everybody. Alexandria was a sample of positive integration achieved by humanity and the peace and advancement it could generate, and so Abdelmeguid keeps on looking back at Alexandria's glorious unsectarian past. All this may make it sound like Alexandria was just the city with its multiple faces. Therefore, is there a typically Arab city? If yes, what characterizes it? The ongoing discussion seeks to enlighten the situation.

EL-Bishr (2013) discusses the fact that the growth of Riyadh into a modern city was not to the taste of everyone. When an atmosphere of extremism permeates the city in the 1970, opposing the social transformations which changed it, it made many victims, including the city itself, which lost some of its flexibility as a driving force of modern cultural innovation. Both actual and fictitious cities are dealt with in the selection we chose to review. The random universal city is also this fictitious place where hardly realistic stories like death, destruction of societies, dispersal and losses of identity (Khalifa, 2013), uncanny encounters (Ghazali, 2014; al-Khamaisi, 2013; and Nasrallah, 2014; Fadel, 2014; Amir Tag Elsir, 2014) happen. In these stories, people are caught in tragedies or they pursue the impossible, ending up losing or destroying everything they can, including themselves, unless they are fortunate enough to experience the classic happy ending, which is the case of Laredj, (2014) who is lucky to learn a lesson through his grandfather's life experience. It is not only in Western cities that a person can self-realize and achieve great heights or relief, as is often recounted in both realistic and fictitious literature (Ismail, 2014).

One can learn from other societies, yet examining one's own society is another source of learning. Therefore, the Arabs like every people, need to learn from the outside world in order to achieve progress (Lahbibi, 2013). Some knowledge of history is good preparation for understanding life's challenges. This is why the past should not be forgotten or misrepresented (Mourad, 2014) whatever the fear of the possible negative effects of its influence on the present.

In the modern Arab city, it may indeed be difficult at times and in places to tell justifiable from unjustifiable 
activities (Nasrallah, 2014). This is well related by Al-Rikabi (2014) in his rendition of the general crisis that prevailed in Iraq from the end of Ottoman rule till U.S. occupation in 2003. While some people endured indiscriminate rampage, others were exploiting occupation in their own personal interests, at times for survival. This resulted in more contempt and indignation, nurturing craze for retribution involving 'the-what's-its-name' or Iraqi Frankenstein (Saadawi, 2013). It is the prevailing atmosphere in Baghdad and indeed many Arabic cities in turmoil (Iraqi occupation, Arab Spring, and ISIL ordeals), unrecognizable entities where even criminals seem impossible to identify.

Arabia does certainly have an identity or identities. Then there have to be Arab cities, both in reality and in fiction. We can only create from what we have; therefore, even if we create, we are somehow depicting reality if in an original manner. Talented writers can transport their readers into times and places and have them witness the stories discussed in their works. As Balzac (1835) had it, we are realistically analyzing the "social species" in a keener or less keen way.

Everything we do bears a consequence. The city may be a setting, a myth, an actor, or something else that induces plots where crime and interactions of any sort are often involved. The novel, or intertextuality between novels, represents these integrals of life.

Arabia used to be classically represented as rural and desertic, with nomad Bedouins and camels. This is only a stereotype, in sharp contrast with the reality in many cases. Typically, Arab cities have long existed even before the West exported their idea of a city to Arab land. We will expand on this in later sections. Some of the early Arab inventions and discoveries were made in those cities. This is not to say that the rural and desert view was totally unfounded. Some nomad Bedouins and rural people in general have often seen them and what they represent as mysterious and dangerous (Hugo, 1831; Balzac, 1835; and Zola, 1885), yet many other people consider them as opportunities for progressing and fulfilling life expectations.

In any case, they point to the values, ideals, and cultural evolution of a society. Put otherwise, cultural legacy accumulated over so much time may be destroyed or hidden in the 'jungle' of cities, but cities also contain the keys to resuscitate or unravel it for present and future generations to change the city both culturally and physically. Says Hugo (1831), "l'architecture est le grand livre de l'humanité".

Throughout their lives, people have often been associated with certain places, entailing a correlation between the individual and the place as each depends on the other. One such place is the city, and it is one of the most significant aesthetic elements in the construction of the novel, since the events of many stories revolve around it. (Shitwī, 2002: 27). It appears that cities depend on the concerted actions of its dwellers to develop the way they do and maintain their identities. However, as much as cities depend on people for their identities, city dwellers also depend on their city for their social and individual developments. This includes cultural and economic development. Therefore, the city is both a product and producer of culture. A central question of this study is how accurate/fictional the perceptions of this dynamic interrelationship are. How were individual lives changed over the processes of city growth, mobility and global interaction? How does the city affect people's mentalities, way of life, and environments? This is investigated by studying works of scholars who cast a critical look at the Arab city, as it holds a substantial place of the imaginary of Arab novels.

The presence of the city is highlighted on two levels: firstly as the molder of events (as in Laylah Wähedah fi Dubai $)^{1}$, and secondly as an incubator of a series of events which provide the urban atmosphere and setting for the literary work (as in Al-erhābi 20). ${ }^{2}$ Such a big place and intense activity as the city is bound to initiate advents of various natures, including cultural and intellectual. Its weight also inevitably impacts and reorients the course that imported events will take. The blending of these realities is at the core of the relationship between the city and the novel.

This symbiotic relationship between the 'city' and the 'novel' deserves looking at. Novelists often use aspects of the city in their works. In turn, the city becomes immortalized in their work. What is the city in novelistic literature? Is it real? Is it fiction? A setting? A character? What role does it play? How does it depict reality? These are the questions discussed in this article.

Over time, the actual city seems to change whereas the city in the novel remains the same. For the past three centuries, the city has continued to provide a generous and valuable source of material for novelists who amply use this resource and its icons to produce such work as Les Misérables (Hugo, 1862), Oliver Twist (Dickens,

\footnotetext{
${ }^{1}$ One Night in Dubai, by Hānī Naqshabandī, who portrayed the city of Dubai as a heroic character.

${ }^{2}$ Terrorist 20, by Abdullah Thābet, whose narrative focused on the Asir region and the city of Abha.
} 
1839), and in the Arab world, Season of Migration to the North (Salih, 1966), Alexandria 47 (Abdulfattāh Rezq, 1984), not to mention Rajaa Ālim's works ${ }^{3}$ featuring Mecca and Mahfouz's ${ }^{4}$ on Cairo.

According to Elisabeth Guerrero, the city is not only built of towers of steel and glass, but is also a product and producer of culture (Lambright, 2007: xi). The city is a fertile place of contradictions as it is a living organism that reflects the life that occurs within it. Goldmann (1957:7) asserts, "The novel form is representative of everyday life". The city creates the world before being used as a depiction of the world. Thus, what the novelist depicts is just an idea of the city and not the city itself. In addition, the novel's place might be a location created in the writer's imagination by drawing on specific elements of reality. As Lehan (1998:7) states, "Writers of literature have relied on imaginative systems", although the construction of the novel's city is based primarily on the actual city. In the Arab world, this is the case with Cairo in the works of both Naguib Mahfouz $(1956,1957)$ and Yūsif al-Gu'îd for example. Thus, it might be important to try and strike a balance between reality and imagination.

The vision that the Arab city in literature is only the actual city is not fully consistent with some critics' views. For example, Gharaibah notes that most places in the Arab novel are derived from the imagination rather than reality. Some people would argue that the depiction of places in the Arab novel reflects the organization of villages, however large they may be. In forming a realistic image of a supposed place described as a mixture of desire, dream, and reality, it is not certain whether the writer is dealing with a real place or an imaginary one; or whether the writer meant one particular city or another one, absolutely unimaginable (Gharāibah, 2004).

Consequently, the recent interest in the study of the city in the Arab novel highlights a critical variation between the reality of the Arab city and the way it appears in the novel. This is why some people would argue that the depiction of places in the Arab novel reflects the organization of villages, however large they may be. But the composition of large villages does not correspond to the makeup of the modern city as a product and producer of culture.

There are critics who even maintain that in some way the Arab City is inexistent (Al-Mahmoud, 2006: 23). Mohammad al-Muwalihi's work is a typical example of the belief that it is Western cities such as Paris that are imported into the Arab novel, but that the Arabs do not really have their typically Arab cities so to speak.

There are writers like Al-Nusayyer, 2007: 12 who thought that some people discussing the Arab city do not know the nature of the relations between the city in question and its representation in the novel. "The rise of the Asian city is more than a story of the built environment or the engulfing of other forms of life by urbanism" (http://campuspress.yale.edu/asiancities/concept-note-part-2). Their ignorance of the interrelations that constitute the "fabric" of the modern Arab city could be blamed on their ignorance of the structure of the city's class system and activities, and its impact on the dynamic transformations within.

If the increase in distances people covered to go to their workplaces and the change in the way they got to those places (Lynch, 1960, and also Gulick, 2007) is seen as a parameter or condition for a locality to be called a city, then cities may have only emerged in the 19th century. Thus, it is necessary for authors to know the city, its civilization, urbanization processes, history, and religion of the Arab world.

The Arab civilization is not only the harsh civilization of the valleys and barren deserts. "It was in the Arab land that man first organized into a settled form of society, cultivating grain and raising livestock, establishing cities and promoting diverse skills and occupations" (http://www.alhewar.org/ArabCivilization.htm). Waving the question of the existence or not of the Arab city is posing the question of the cultural evolution of Arabia, of the transmission of their knowledge and know-how from earlier days to the present. This is what literature, with architecture and art (Hugo 1831), better than history books or technology, accounts for so eloquently.

No one can reasonably dispute the precedence of the civilization of Ancient Egypt that brought us the so praised pyramids and the mathematics to build them. However, the Arab civilization in general seems to be on the decline. Will it ever rise from its ashes? In any case, it may be too early to write it an epitaph in this ever changing world. Nations rise, reach their apogees, and fall; other nations take over, followed by yet others, and so on. Nothing augurs of the non-return of Arab-Islamic civilization to the front of the international scene. Yet if it is to be, it will necessarily be through the city and its traditional function of dynamic instigator of creativity, supporter of innovation, booster of activity, and pusher of intellectual borders. Whether it is about Arabia or anywhere, peoples should learn about and know their history, entrenched in it but open to the fruitful exchange

\footnotetext{
${ }^{3}$ Such as Tawq al Hamam 2010

${ }^{4}$ Such as Awlād Hāratnā and Naguib Mahfouz's trilogy.
} 
with other peoples; this is more veracious today than it has ever been before. Embracing positive change and enriching oneself with wider external input can only be for the good of self and others. Nostalgia and attempt at resuscitating the past are not the solution. If one is true to oneself and dynamically flexible, then one is well set to resist the storm of cultural up rootedness, insidiously instilled in people - with its load of negative consequences - that seems to be sweeping across fragilized nations and swaying the world across.

The spirit and soul of the old Arab city has aged and changed as much as the city itself has physically. Narrators have been telling it with a focus on the wrongs; it is high time they proposed solutions to the issue, for it can still be healed, however deep the scars may be.

The long history of urbanization in the Arab world reveals that the city has played a substantial role in its regard culture, which was originally based on life in cities (Hamdān, 1996: 5). Abu Zeid states: today's Arab is the product of a long development process undergone by the assembled scattered people of Arabia. Peaceful coexistence and stability within the city was achieved by reconciling tribes such as Aws and Khazraj, together with their allies, including the Jews who lived among the Arabs. This restoration was one of the first priorities of the Prophet (pbuh) ${ }^{5}$ of Islam.

Some Arab dictionaries indicate that civilization, urbanization, and the city are organically related. The word 'city'/ madina is derived from the verb 'M D N' which means settle in a given place, while 'urbanization' tamaddun corresponds to the ethics of the people of the cities who progressed from a nomadic way of life to a state of stability, which implements schooling and education. 'Civility' madaniyyah means progress in scientific, artistic, literary, and social development which flourishes in the cities (Shahīd, 2007). The word 'civilization' Hada ârah derives from the root ' $H$ D R' which means attendance (as opposed to absence) and residence in urban areas. A Bedouin is often said to be civilized if he follows the morality of urban people, adopts their habits and even way of life. This also means permanent residence in the town or city, which, contrary to nomadism, is viewed as correlating with civility and progress (Ibn Manzhūr, 2005: itme of M D N and Ḥ Ḍ R). ${ }^{6}$

It is clear from the above that the words "civil" and "civilization" are intrinsically linked to the city and not to the desert or the countryside and therefore, the Arab civilization is essentially a civilization of cities. Consideration of the Arab novel requires identifying the position of Islam vis-à-vis the issue of the city and civilization as the Arab writer is generally religious and conservative by nature. Cordesman states, "Saudi Arabia is an intensely conservative society whose values are religious rather than secular" (Cordesman, 2009:307).

In the Islamic city, the concept of nation among the multiplicity of identity emerged as the Prophet (pbuh) established the nation's religion to all Muslims in and outside of the city. Furthermore, he also established a wider political nation concerning to Muslims and non-Muslims alike. A good illustration of this is the integration of Muslims and Jews in one political nation united by geography and political rights. Therefore, the concept of nation-state with attached services and related growth developed as Islam expanded to peoples within and outside the city (Young, 2010. vol 2: 503). Europeans contemplated the rise of Arabs in varied sciences and strove to do likewise.

\subsection{Islam's Perspective on the City}

If religion is, by its nature, a collective process, then it corresponds with the nature of cities and humans as sociable beings. This interaction has consequently promoted the emergence and growth of many cities. Some unique phenomena of the city in the Islamic world are the Friday prayer and the three days following Eid al-Adha $^{7}$, which should only be performed in cities (Al-Mulaggen, 2008: 439/7). Because it is a collective worship that encourages communal interaction, the Friday prayer should gather no less than forty people, according to some scholars. This would indicate a preference for cities and urban lifestyle over small villages and tribal ways of life.

The term city is mentioned 14 times in the Holy Qur'an and the word village 33 times. Names of villages are often mentioned in relation to basic feelings such as hunger, fear, joy, and greed. For anything having to do with the mind, the word city is preferred. In this context, the city has been shown in a positive aspect.

More than once in the famous Muqaddima, Ibn Khaldūn indicated how Al-Bukhārī cautioned against the dangers of extreme preoccupation with agricultural implements (Ibn Khaldūn, n.d: 142, 394). "Agriculture was definitely

\footnotetext{
${ }^{5}$ Furthermore see Haykal, M. H. 2010. Life of Muhammed Islamic Book Trust p: 175-236.

${ }^{6}$ For more detail, See Ibn MANZHŪR, I. 2005. Lisān Al-Arab, Beirut, Dār Al-Kotob Al-ilmiyah.6(13). p 47, 126.

${ }^{7}$ Some scholars explain this hadith by saying that, there is no Friday and Eid prayer outside cities. ('Eid prayer' and Eid al-Adha means An Islamic festival commemorating the prophet Ibrahim's willingness to sacrifice his son Ismail to Allah (also called the greatest day of Hajj)).
} 
considered one of the lowest occupations, suitable only for the meanest type of human being" (Badawi, 1985:27). This may be argued against with the numerous utterances praising agriculture in Islam. In any case, since the city is not the place for agriculture, the above quote maintains its virtue of being associated with the mind.

Islam has also greatly contributed to the development and promotion of architecture and civilization in general. Arab civilization essentially grew up in Mecca and Medina and flourished in Damascus, Aleppo, Baghdad, Cairo, and the cities of the Maghreb and Andalusia. In these cities flourished literature, arts, ideas and doctrines. Several aspects of the civilization thrived, such as grand mosques, schools, and major translation centers (Zikr-ur-Rahman, 2004: 176); that have had great impact on humanity. Religion and urban culture made the transfer of political power from one city to another an open process. ${ }^{8}$ The three revealed monotheistic religions (Judaism, Christianity, and Islam) spread primarily from, within, and through cities to spearhead civilization. Prophet Mohammad (pbuh) was born in the city of Mecca, then migrated to another city, Medina, breaking the idea and practices of restricted tribal circles and expanded their horizons to turn their members into civilized people. The Prophet (pbuh) urged Muslims to seek education - fostering an Arab tradition among some individuals - and get civilized. Many did, which at the time gave them great educational advantage over the rest. Missionaries sent to, and mosques built in, various places to instruct peoples played an invaluable role in this regard.

Innumerable schools were established to teach subjects including the Qur'an, hadiths (Muslim tradition), fiqh (jurisprudence), balagha (rhetoric), etc. The city being diverse, everyone, including women and non-Muslims, was allowed to seek knowledge and participate in urban life. Civility prevailed. Schools grew in number and size and specialization developed, as did scholarships and pensions and dormitories to accommodate learners. Teachers were paid by government and private contributors.

The foregoing pleads for the existence of real cities, which are abundantly accounted for in different literary genres, whether realistic or fictional. Traveling in all directions to different cities in search of knowledge was a common practice. As cities were expanding and developing civilization, so were civilized people changing their face and perceptions too, concretely and through their fictitious accounts of it. Many cities were built to spread Islam and welcome converts. The expansion of this religion throughout the world has had an immense effect on urban planning, design, and life. It is essential for the centralization and administration of people. This speaks to why cities have to respond to the reality of the environments: natural, sociocultural, and religious (cf. Saoud, 2002 for the design principles and components of the Muslim city).

\subsection{Mecca: A City of Civilization, Culture, and Religion}

According to Kevin Wright, Director of the Global Organization for Religious Tourism, more than six million visitors from abroad travel to Saudi Arabia each year for pilgrimage (Hajj and 'Umrah, ${ }^{9}$ resulting in an estimated \$7 billion per year (2009). The Saudi Minister of Pilgrimage stresses that, during the month of Ramadan in 2008 (September), Mecca received more than 3.2 million visitors from both home and abroad (Agency, 2009). Thus, a place like Mecca cannot be left 'out of the circle of cities'. ${ }^{10}$

\footnotetext{
${ }^{8}$ Transmission of the Caliphate from Medina to Damascus in the era of Caliph Mu`āwiya was a case in point; the transfer of political power from cities to other cities occurred after that during the heights of the Islamic empire when Arabs were in positions of power.

${ }^{9}$ Pilgrimage to Mecca - the so-called minor Hajj-unlike the Hajj proper, need not be performed at a particular time of the year; in addition, its performance involves fewer ceremonies. See WEHR, H. 1980. A Dictionary Of Modern Written Arabic. In: COWAN, J. M. (ed.) 3 ed. London, Beirut: acdnald \& Evans Ltd. Librairie Du Liba P. 643.

${ }^{10}$ In Qatar, Mecca (which is located in Saudi Arabia) was chosen as the capital of Islamic culture in 2006, a testament to its long cultural and influential role. Chancellor of Umm Al-Qura University Dr. Nasser Al-șāleh confirmed that a large number of lectures, papers, and seminars are presented on this occasion, along with more than 300 research studies and 500 events examining the impacts of Mecca in many places around the world ('Ābdullah, 2005). In addition, Umm al-Qura University in Mecca sponsored the publication of more than 100 books on Mecca and its impact, written by local and global authors-all in one year. Upon choosing Mecca as the capital of the Islamic culture, King Abdulaziz University presented numerous activities, such as:

A. 'The holiness of Mecca and its grace', a study of the place and meaning indications as mentioned in Psalm 84 in the Bible (by Dr. Laila Zarour from the Department of Geography).

B. 'The holiness of Mecca in the Arab poetry' (by Dr. Ibtisam Hamdan from the Arabic Language Department).

C. 'Citizenship' (by Dr. NouraAlsaad).

D. 'The Alkaabasidana through history' (by Dr. Fathia Alqurshi from the Department of Social Studies).

E. 'The shaping of the book of Mecca' (by Dr. Huda Alamode).

F. 'The ecological characteristics of Mecca and their effect on the pilgrims' (by Dr. FaydehBoukari from the Department of Geography).
} 
A number of writers and critics believe in earlier views of Al-Mahmūd (2006) and link cities to the industrial revolution, although classifying places are cities might not necessarily be related to its occurrence. Thus, some religious cities such as Jerusalem and Mecca might have missed the industrial revolution, yet have retained the features and characteristics that classified them as cities. In addition, the idea that the city was a deliberate creation of humans is subject to variations in culture, geography, and civilization. This would apply to many Arab cities beyond the size and population census. "Indeed, urban studies and most of the scholars' definitions can be applied to the Arab city; no one can mistake the way of life in the village with the one in the city" (Ghālī, 1995:12).

What also supports the existence of the Arab city is the existence of many books which include the word of a city, such as ${ }^{11}$ Al-madīna wa Al-turāth, ${ }^{12}$ Al-madinah wa Al-shi'r Al'arabi Al-mu āșir, ${ }^{13}$ Madinat Al-Riyadh AbraAțwār Al-ttārīkh, ${ }^{14}$ The City in the Islamic World, and ${ }^{15}$ Madinat Morākish. Generally speaking, in terms of fictional works, several novels also draw their titles from names of cities and other places, including Al-ḥamam Lāyațir fi Buraydah (2009) by Yūsif Al-mohayemīd, ${ }^{16}$ Sūr Jeddeh (2009), ${ }^{17}$ Lāyūj ad Mușawwer fi 'Unayzah (2008), ${ }^{18} L \bar{a}$ ' a ḥad fi Tabūk (2008), and ${ }^{19}$ Yamorrūn be Alzhahrān (2008). ${ }^{20}$

In conclusion, the Arab city may be perceived as both reality and fiction because it may be both, especially in the Arab novel. Fiction may be very powerful, but it is known that reality is even more powerful because it is the source of inspiration. Simply reading a novel such as Al-rraj`a Al-ba ìd by Fu'ād Al-Takarlī exemplifies understandings of the city, highlighting the relationship and the disparity between urban and rural areas from the perspective of the author, who first lived in a rural area and subsequently taught in cities. Understanding this leads the reader to realize that the Arab city does exist in Arabic fiction as it does in reality. As for Islam's perspective on the city, it is enlightening to read Saoud's (2002) Introduction to the Islamic City.

\section{Methodology}

This is a descriptive study that investigates perceptions of the Arab city among colleagues at the Department of English and Translation in Qassim University, and as exposed in the literature the authors reviewed. It was aimed at documenting how Arab cities are viewed in relation to Western cities in particular then suggest intelligent use of this understanding to limit the negative impact of differences on Arab societies and on relations between the Arab and the Western worlds.

\subsection{Research Design and Procedures}

As indicated above, this paper sets to describe and analyze views on what would constitute an Arab city. We produced the questionnaire below that we distributed to 20 of the 25 faculty currently exercising in the English department and received 15 answers. We wanted to distribute it to all the colleagues but did not manage because some asked us to wait for a more convenient time. The answers were to be appraised against the various readings done in both history and literature to answer the study questions; triangulation strengthens qualitative research (Holtzhausen, 2001). All of the participants, except one British citizen, were Arabs of different nationalities. Then we examined the data collected to get an idea of how Arab cities were perceived and how the insights

G. 'The women of Mecca and the scientific life' (by Dr. Ibtsam Khashmeri from the Department of History).

H. 'The canto on the footsteps of the beloved prophet Mohammed peace be upon him' (by Prof. Aisha Al Qarni from the Department of Islamic Studies).

I. Nada Burnji from the Department of European Languages prepared visual displays that have shown the cultural aspects of Mecca. She also conducted a presentation that included some rare antique pictures taken for the Haram in Mecca. Dr. Ibtisam Kashmeri prepared four visual displays done by the students of the Department of History. Other displays were presented by students from the Departments of Psychology and Social Studies. For more, see Center, F. R. (2009). 'Lectures and Sessions.'King Abdulaziz University FAH Research Center. Retrieved 6-5-2009, from http://rca.kau.edu.sa/Content.aspx?Site_ID=127\&lng=EN\&cid=2263.

${ }^{11}$ By Ahmed Mațlūb, translated as the city in the heritage.

${ }^{12}$ ByMokhtār Ali Abu Ghālī, meaning the city in contemporary Arabic poetry.

${ }^{13}$ By Hamad Al-Jāsir, meaning the city of Riyadh through the phases of history.

${ }^{14}$ By Salma K and Renata Holod.

${ }^{15}$ By by Ahmed Al-Madīn̄.

${ }^{16}$ By Sa`ìd Al-wahhābī.

${ }^{17}$ By Khāled Al-bassām.

${ }^{18}$ By Muṭlag Al-boluwī.

${ }^{19}$ By Fāli Al- aghayyir.

${ }^{20}$ In addition, Banāt Al-Riyā 
acquired could participate in settling the relations between Arabia and the West.

\subsection{Questionnaire}

We appreciate your filling out this questionnaire designed to gather your perception of the Arab city and its specificities in the global context, and how you think it affects culture and civilization.

Please answer these questions as appropriate. If necessary, do not hesitate to extend your answers to the dotted lines below this questionnaire and a separate sheet if need be.

1. Do you think there is any such thing as an Arab city, essentially different from other cities in structure and 'soul?' Yes No Not Sure

2. Can you please support your answer?

3. Does the Arab city only exist in literary fiction? Yes No Not Sure

4. Some people believe that urbanization and cities originated with the advent of the Industrial Revolution. Do you agree? Yes No Not Sure

5. If you do not agree, when do you think they can be traced back to?

6. Why do you think so?

7. How do you think the Arab city, if it exists, socioculturally speaking, compares with other cities in the world, in particular Western cities? Discuss similarities and differences.

8. If the Arab city can be characterized as specific, how do its specificities affect culture and civilization?

End of questionnaire.

Supplementary answer space 
Thank you for your cooperation. M. S. Diallo. \& A. Al-Fauzan

\section{Results}

This paper studied perceptions of the Arab city. To do so, it looked at people's opinion on whether such a city existed or not; whether it was real or imaginary; its relations with other cities; the similarities and differences; and the effect of all this on culture and civilization. Fifteen questionnaires were returned out of the twenty distributed to the English and Translation Department of Qassim University. There was a response rate of 75\%. The researchers tried to reach all 25 faculty members and have them answer the questionnaire but didn't manage as some didn't seem to be interested. Below are the data collected.

1. Do you think there is any such thing as an Arab city, essentially different from other cities in structure and 'soul?' Yes: $9(60 \%)$ No: $3(20 \%) \quad$ Not Sure: $3(20 \%)$

2. Can you please support your answer?

The architecture and culture/way of life are different: 8 (53\%) (No answer): 7 (47\%)

3. Does the Arab city only exist in literary fiction? Yes: 3 (20\%) No: 9 (60\%) Not Sure: $3(20 \%)$

4. Some people believe that urbanization and cities originated with the advent of the Industrial Revolution. Do you agree? Yes: 3 (20\%) No: 7 (47\%) Not Sure: $5(33 \%)$

5. If you do not agree, when do you think they can be traced back to? To the modern era: 5 (33\%) To the beginning of society: $1(7 \%)$ With the holy places of Makkah and Medinah: $3(20 \%)$ Thousands of years before BC: 4 (27\%) (Don't Know): 2 (13\%)

6. Why do you think so?

Europeans settlers organized the first cities in the Arab world to manage their colonies: (27\%)

Cities have always existed since big groups of humans started organizing themselves in a structured way: 5

(33\%) There were no cities before Makkah and Medinah: 3 (20\%) (Don't Know): 3 (20\%)

7. How do you think the Arab city, if it exists, sociocultural speaking, compares with other cities in the world, in particular western cities? Discuss similarities and differences. Similarities: sizes, infrastructure and administration: $12(80 \%)$

Differences: prevalence of Islam; importance of family; ways and customs including socialization and food, systemic separation of genders in most cases: 13 (87) No comparison: 2 (13\%) If the Arab city can be characterized as specific, how do its specificities affect culture and civilization?

As an addition to universal culture: $3(20 \%)$

By the concentration of mosques and their influence on people: $6(40 \%)$

By the fact that new ideas and practices often pass through the filter of Islam: 3 (20\%) (No answer): $3(20 \%)$ End of questionnaire.

Supplementary answer space "I would think it would be more appropriate if there is a little explanation of what you mean by 'Arab city": 1

Fortunately, only one respondent made such a comment about the questionnaire. As researchers, we thought that what we meant by Arab city was clear, especially as conveyed by Questions 1 and 7 .

The first question yielded $60 \%$ of yes answers and $20 \%$ no's. Another $20 \%$ declared not to be sure. This suggests that the respondents generally believed in the existence of a different identity for the Arab city. Such a city would be characterized by both its architecture and culture (53\%). The same $60 \%$ who believed Arab cities had their 
own marks and the $20 \%$ who believed they didn't also respectively thought that those did only exist in literary fiction.

As to whether cities in general and urbanization were a product of the Industrial Revolution, $20 \%$ answered yes, $47 \%$ no, and $33 \%$ not sure. Therefore, though a sizable percentile were not sure whether the Industrial Revolution originated cities, close to half did not credit it with urbanization, though it has played an undeniable role in their rise. Although 33\% said they were not sure, $87 \%$ went on to indicate they believed cities predated the Industrial Revolution by centuries if not millennia, with $20 \%$ dating it to the pre-eminence of Makkah and Madinah as trade and religious centers. This is corroborated in www.boundless.com/world-history.

However, over a quarter (27\%) of the participants indicated that European settlers started modern cities in Arabia. While 87 of respondents believed that Arab cities were different from their Western counterparts, when it comes to ways and customs, $80 \%$ also thought they were similar in sizes, infrastructure, and administrative configuration. These similarities would not affect Islam's precedence on all aspects of life, as $60 \%$ reckoned this prominence.

These results show that respondents generally believed in the existence, beyond literary fiction, of an Arab city that is essentially different from other cities. The difference is thought to be not only structural and infrastructural, but also cultural and civilizational. Cities in general and Arab cities in particular would predate Western colonization and even the Industrial Revolution, going back to at least the economic hubs and religious centers of Makkah and Madinah, if not many thousands of years earlier. Respondents also claimed that the differences mainly reside in the traditions and the impact of Islam on the society.

\section{Summary and Discussion}

This paper was based on data collected from the questionnaire and different readings to study perceptions of the Arab city and contemplate how these perceptions and their influence on Arabs can help bridge the comprehension gap between them and the West. Description of what is noticed and felt was used to this effect, along with insights from the pertaining readings carried out. The data collected and the readings done clearly indicate that respondents believed Arab cities have their own identities despite sharing some characteristics with other cities. This is not surprising to researchers as we thought that what triggered the debate about the existence or not of an Arab city that led to this research was the presumption of its existence. Moreover, it is common knowledge that the Arab civilization is ancient, as is supported by countless artifacts and writings. Therefore, they would not credit the Industrial Revolution or colonization with starting their cities, though it may have played a big role in the rise of Western cities (http://webs.bcp.org/sites/vcleary/ModernWorldHistoryTextbook/ IndustrialRevolution). Suffice it to read the history and consider the heritage - part of which is currently being senselessly destroyed - of Mesopotamia and Assyria for example, to understand this position. If cities in the wider world have influenced modern Arab urbanization, themselves owe a lot to older Arab cities.

\section{Limitations}

One limitation of the study is its confinement to the current faculty of the English and Translation Department of Qassim University, KSA. Another limitation is its failing to cover the totality of the faculty, some being away in Australia, Britain, or the United States completing a graduate degree. Also, of the 25 currently teaching in the Department, 20 were distributed the questionnaire and only 15 answered it. Yet another limitation may be the Arab background of all respondents - though from different countries - but one British national.

\section{Recommendations for Further Study}

This study doesn't pretend to be exhaustive by any means. Additional research could be conducted on the topic for more comprehensive information leading to better comprehension and smoother communication between different peoples. People tend to be more tolerant or accepting of what they understand. In this era of globalization, mutual understanding is more than ever a necessity for peaceful coexistence. Within this dire situation of denied liberty for some, mostly Arab countries, in both the Middle East and the Mediterranean; the example of Europeans, with Germany ahead, providing vital relief for tormented humans, is a striking example of working empathy. Not only is this an example of solidarity with desperate people, it also provides the benefactors with much needed labor. We may learn from this situation that we are all indeed sailing in the same ship, and that we need to take care of each other instead of pulling into our own individual shells. Against misguided minds who bring about all the chaos and spread death on land and in the seas, we say "since night issues from the thrones, let the light come from the tombs (Hugo, 1878, page not indicated).

\section{References}

Abdelmeguid, I. (2014). Clouds over Alexandria. Cairo: Dar al-Shorouq. 
Agency, S. P. (2009). "Mukhālafāt Sharekāt Al-'Umra Inḥasarat Kathīran Binnazhari 'Ilā Tarāju' Shakāwā Al-Bishr, B. 2013. Love Stories on Al-Ashā Street. London: Dār Al-Sāqi Al-Mu'tamirīn". Al-'Iqtiṣādiyya. 24-1-2005. 5584 ed. a īfat Al'Iqti ād Al-'Ikturūniyyah.

Al-Hilāl, M. T., \& Khān, M. M. (2006). Translation of the Meanings of the Noble Qur'ān in the English Language.

Al-Madīnah: K.S.A King Fahd Complex for the Printing of the Holy Qur'ān.

Al-Maḥmūd, M. (2006). "Najīb Mạ̣fūzh. Al-Riwāya Kakhițāb Tanwīr̄ī (1)". Al-Rriyāọ. 14-9-2006. 13961 ed. Al-Rriyāọ, Mu'assasat Al-Yamāmah Al-Ṣaḥafiyah.

Al-Mulaggen, O. B. A. B. (2008). Al-Tawḍịh Lisharḥ Al-Jāmi' Al-Ṣaḥị̣. Qatar: Wazārat Al- 'Awqāf wa Al-Shu'ūn Al-'Islāmiyah.

Al-Nușayyer, Y. (2007). "Baghdād Tatalammas Ṭarīquhā 'Ilā Al-Riwāya". Al-Sharq Al-Awsaṭ. 31-10-2007. 10564 ed. Saudi Arabia.

Al-Rikabi, A. K. (2014). The Sad Night of Ali Baba. Baghdad: The Arab Institute for Research and Publishing. 'Ālim, R. 2010. Tawq Al-Hamam. Casablanca: Al-markaz Al-thaqafi Al-Arabi.

Badawi, M. M. (1985). Modern Arabic Literature and the West. London: Ithaca Press. Balzac, H. 1835. Le Père Goriot (Old Goriot). Paris: Edmond Werdet.

Cordesman, A. H. (2009). Saudi Arabia: National Security in a Troubled Region. Santa Barbara: Praeger Security International.

Dickens, C. (1839). Oliver Twist. London: Bentley. https://doi.org/10.1093/oseo/instance.00121337.

Elsir, A. T. (2014). 366. Lebanon: The Arab Institute for Research and Publishing.

Fadel, Y. (2014). A Rare Blue Bird that Flies with Me. Lebanon: Dār Al-Adāb Linasher wa Al-Tawzia.

Ghālī, M. A. A. (1995). "Al-Madīnah fî Al-Shi'r Al-'Arabī Al-Mu'ạṣir: Al-Madīnah Mawḍūan". 'Ālam Al-Ma'rifah, vo1. 196. 7-13.

Gharāibah, I. (2004). "Rehlat Ḍaw'o: Tahadiyāat Tuwājih Al-Riwāya Al-'Arabiyya". Al-Ma'rifah. Available at: $<\mathrm{http}: / /$ www.aljazeera.net/NR/exeres/2D7E8C26-4603-40C9-AC33-AF7C62DFD930.htm > [Accessed 17-4-2009].

Ghazali, I. (2014). The Season of Pike Fishing. Lebanon: Arab Scientific Publishers. Goldmann, L. 1975. Towards a Sociology of the Novel. London: Tavistock Publications.

Gulick, J. (2007). Images of an Arab City. http://dx.doi.org/10.1080/01944366308978063

Ḥamdān, J. (1996). Al-madinah Al’arabiyah. Ketāb Al-hilāl, 549, 3-14. Cairo: Mùassasat Dār Al-Hilāl. Haykal, M. H. 2010. Life of Muhammed (Al-Faruqi, I. R. Trans). Kuala Lumpur: Islamic Book Trust.

Hugo, V. 1831. Notre Dame de Paris. Paris: Arléa.

Hugo, V. 1862. Les Misérables. Paris: Garnier Frères.

Hugo, V. 1878. Oration on Voltaire. Delivered on May 30, 1878 (the one hundredth anniversary of Voltaire's death) in Paris.

Ibn Manzhūr, I. (2005). Lisān Al-'Arab. Beirut: Dār Al-Kutub Al-'Ilmiyah.

Ismail, I. F. (2014). The Phoenix and the Faithful Friend. Lebanon: Arab Scientific Publishers.

Khaldūn, I. (n. d.). Muqaddimat Al-'Allāma ibn Khaldūn. Cairo: Dār Al-Salām. Khalifa, K. 2013. No Knives in the City's Kitchens. Cairo: Dar Al-Ain Publishing. Khamaisi, A. 2014. god'd land of exile. Cairo: al-Hadara.

Wright, K.. (2009). "Religious Tourism in the Middle East". Al-Watan E-newspaper. Available at: $<$ http://www.egyptiangreens.com/docs/general/index.php?eh=newhit\&subjectid=15070\&subcategoryid=26 $0 \&$ categ oryid $=36>$ [Accessed 10-5-2009].

Lahbibi, A. (2013). The Journeys of 'Abdi, Known as Son of Hamriya. Lebanon: The Arab Institute for Research and Publishing.

Lambright, A. G. E. (2007). Unfolding The City: Women Write The City in Latin America. Minneapolis: University of Minnesota Press.

Laredj, W. (2014). Ashes of the East: The Wolf Who Grew up in the Wilderness. Algiers: Al-Jamal. 
Lehan, R. D. (1998). The City in Literature: An Intellectual and Cultural History. Berkeley. London: University of California Press.

Lynch, K. (1960). The Image of the City. MIT Press.

Mahfouz, N. (1956). Palace Walk. New York: Anchor Press.

Mahfouz, N. (1957). Palace of Desire. New York: Anchor Press.

Mahfouz, N. (1957). Sugar Street. New York: Anchor Press.

Mourad, A. (2014). The Blue Elephant. Cairo: Dar Al Shorouk.

Mrabet, G. (2012). Western Education in the Arabian Gulf: The Costs and Benefits of Reform. Retrieved from: http://webs.bcp.org/sites/vcleary/ModernWorldHistoryTextbook/IndustrialRevolution on September 25, 2015.

Nasrallah, I. (2014). The Edge of the Abyss. Lebanon: Arab Scientific Publishers.

Rezq, A. (1984). Exandria 47. Cairo: Dar Alhilal.

Roy, A., \& Brenner, N. (2016). Contemplating the Rise of Asian Cities: Workshop and Plenary Session [Monday, May 16, 2016, 4:30 p.m. @ Greenberg Conference Center. Retrived on May 23, 2017.

Sàadawi, A. (2013). Frankenstein in Baghdad. Baghdad: Al-Jamal.

Salih, T. (1966). Season of Migration to the North. Beirut: Al-Dar Al-Qawmiyya lil- Tiba'a wa al-Nashr.

Saoud, R. (2002). Introduction to the Islamic City. Manchester: Fstc Limited. $<$ http://www.muslimheritage.com/uploads/Islamic\%20City.pdf.> [Accessed 1-1-2012].

Shitwīi, I. M. (2002). Al-Ṣirā' Al-Ḥaḍāī fī Al-Riwāya Al-Mașriyya 1973-1990. Riyadh: Dār Al-Rifā̄ī.

Young, N. J. (2010). The Oxford International Encyclopaedia of Peace, vol. 2. New York: Oxford University Press. Zade, A. A. 1980. Al-Madinah Al’’ islāmiyyah. Kuwait: `Ālam Al-fiker, 11, 3-12.

Zikr-Ur-Rahman. (2004). Historical Role of Islam. New Delhi: Anmol Publications Pvt Ltd. ZOLA, E. 1885. Germinal. Paris: Gil Blas.

\section{Copyrights}

Copyright for this article is retained by the author(s), with first publication rights granted to the journal.

This is an open-access article distributed under the terms and conditions of the Creative Commons Attribution license (http://creativecommons.org/licenses/by/4.0/). 